\section{Blandt agenter og intellek- tuelle: Georg Friedrich Nicolai i København 1918}

af forskningsbibliotekar Jesper Düring Jorgensen, Det Kongelige Bibliotek

I begyndelsen af oktober 1914 udsendte 93 fremragende tyske personligheder indenfor videnskab og kunst et opråb til den samlede internationale kulturverden, hvori de navngivne protesterede mod det, de opfattede som ententens løgn og bagvaskelse af Tysklands krigsførelse i Belgien. Til Danmark nåede dette opråb den 5. oktober 1914 , da en dansksproget version publiceredes i Politiken under overskriften: En Henvendelse fra tyske Videnskabsmand og Kunstnere.

I seks sætninger, der alle blev indledt med det kategoriske: Es ist nicht wabr... benægtede underskriverne, at Tyskland var skyld i krigen, at kejserriget på forbryderisk vis havde krænket Belgiens neutralitet, at det havde ladet civile belgieres liv og ejendom antaste, at tyske soldater var faret ødelæggende frem mod byen Löwen, at Tysklands krigsførelse havde ringeagtet folkeretten, og endelig benægtedes ententepåstanden: At kampen mod Tyskland alene var en kamp mod den tyske militarisme og ikke en tilintetgørelseskamp mod den tyske kultur. Disse seks absolutte udsagn var blevet underskrevet "med navn og ære", som det formuleredes. I opråbet var de enkelte underskrivende specificeret efter metier. Der var således 17 udøvende kunstnere, heriblandt billedhuggeren Max Klinger, 15 naturvidenskabsmænd, blandt dem både Wilhelm Röntgen og Max Planck; desuden 12 teologer og 9 digtere.

Blandt de bemærkelsesværdigt få digtere fandtes dog tunge navne som Richard Dehmel og Gerhard og Carl Hauptmann. Herefter fulgte 7 jurister, andre 7 medicinere og 7 historikere, 5 kunstkritikere, 4 filosoffer og 4 filologer, heriblandt den i tiden berømmede nordiske filolog Andreas Heusler, 3 musikere, blandt dem ikke overraskende Siegfried Wagner, og sluttelig fulgte 2 politikere, men blot 1 teatermand, nemlig Max Reinhardt.

Efter navnene at dømme et guldrandet dokument, men bedømt på indhold og baggrund et tvivlsomt papir.

Aufruf an die Kulturvelt, eller Es ist nicht wahr, en titel, som dette skrift også blev kendt under, har på én gang sine forbilleder i Zolas J'accuse fra Clemenceaus avis L'Aurore af 13. januar 1898 og i den erklæring, som de 102 fremragende repræsentanter for datidens franske åndsliv udsendte dagen efter - ligeledes i L'Aurore, - hvor de havde underskrevet en kollektiv protest mod den rettergang, kaptajn Dreyfus havde været udsat for. Denne erklæring er siden gået over i en historisk-litterær tradition som "de intellektuelles manifest," idet denne kollektive udtalelse siden vidtgående er blevet betragtet som den første kollektive, moralske appel i moderne tid fra en række åndspersonligheder, der hermed satte deres gode navn og integritet ind på en konkret politisk sag som en modvægt overfor 


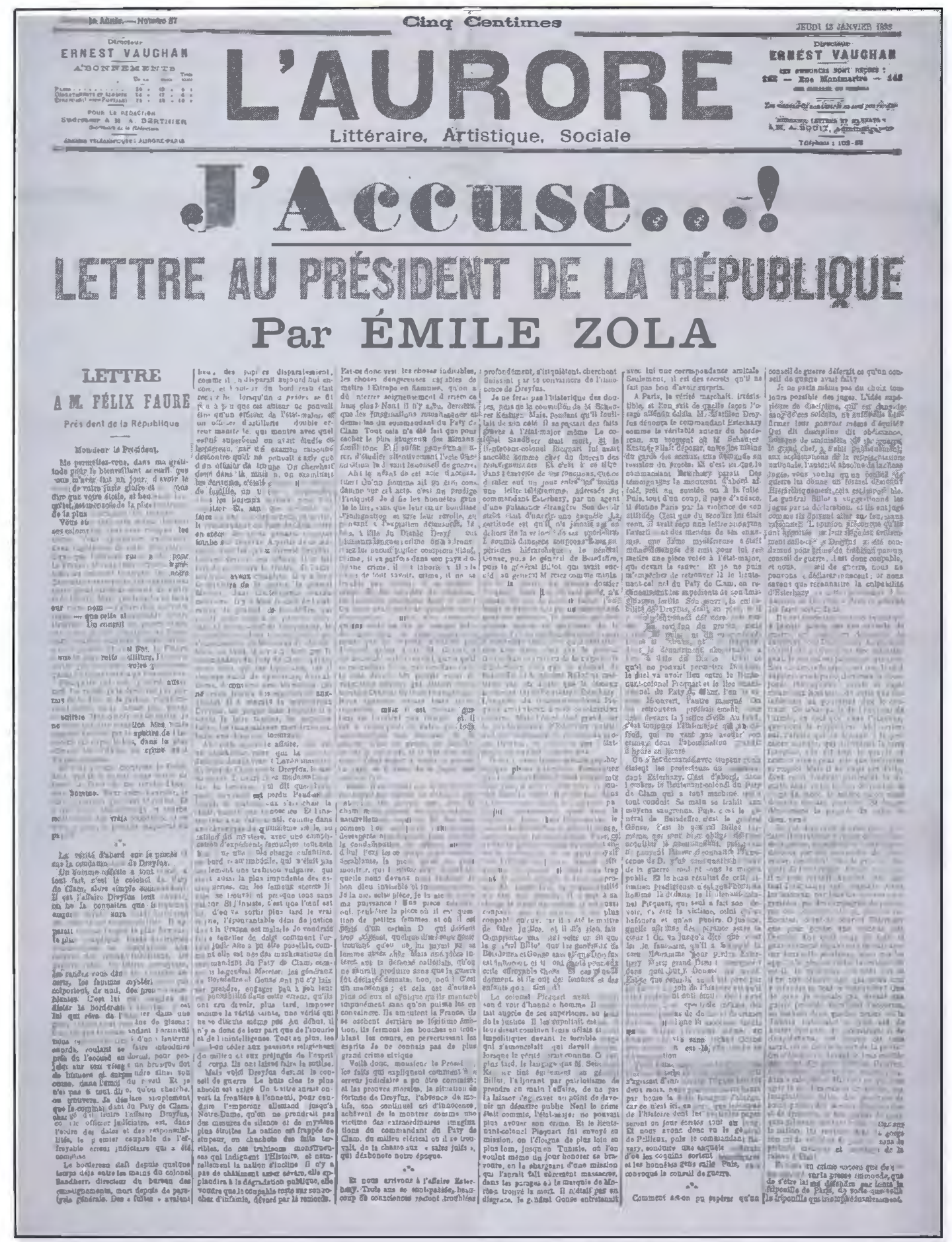

Forsiden af avisen L'Aurore torsdag den 13. januar 1898, med Émile Zolas åbne brev J'accuse ...! angående Dreyfus-sagen. Overskriften lyder: Jeg anklager: Brev til republikkens prasident.

det magtmisbrug og justitsmord, som de så den franske regering og det franske militær begå overfor kaptajn Dreyfus. ${ }^{1}$
Der er noget af den samme appel i "Es ist nicht wahr." som i det franske “J'accuse". Der er ligheder men også 
signifikante forskelle mellem disse to åbne breve til offentligheden.

Begge henvendelser har det til fælles, at de var iscenesat af andre end underskriverne. Aktionen til fordel for Dreyfus var avisen L'Aurores og dens redaktørs, Georges Clemenceaus, værk, mens opråbet fra de 93 fremragende tyske repræsentanter for kunst og videnskab blev formidlet ud i offentligheden af centrumpolitikeren Matthias Erzberger som et led i den propagandavirksomhed, han udøvede for den kejserlige tyske regering. ${ }^{2}$ I begge tilfælde lagde en række personligheder navn til en bestemt ordlyd i en henvendelse til offentligheden, som de nok havde taget stilling til, men ikke formuleret. De kom på den måde til at deltage $i$ et interessespil, de næppe har haft mulighed for at gennemskue fuldt ud, og som kun på overfladen havde at gøre med indholdet af det, de havde lagt navn til, men som på mere diskret måde kunne være til gavn for de kræfter, der havde iscenesat sagen i offentligheden.

For politikeren og journalisten Clemenceau kom Zolas henvendelse til bladet umådelig belejligt. Den bidrog afgørende til hans comeback i fransk politik, fordi det lykkedes ham at skubbe offentlighedens interesse bort fra endnu en kritisk rapport om den såkaldte panamaskandale, der nogle år forinden havde kostet ham sædet i Nationalforsamlingen. $^{3}$

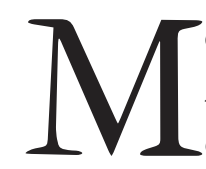
ed hensyn til Aufruf an die Kulturwelt er der den lighed, at dette opråb også formidledes af en enkeltperson med en ganske specifik interesse, der i dette tilfælde var be- stemt af hans placering og opgave som propagandamager for den kejserlige tyske regering.

Matthias Erzberger var fra efteråret 1914 den egentlige, daglige leder af organisationen Zentralstelle für Auslandsdienst, hvis opgave var spredning af tysk propaganda i udlandet samt at virke for den moralske oprustning af den tyske hjemmefront. Erzberger var dog ikke forfatter til opråbets ordlyd. ${ }^{4}$ Det afgørende i denne sammenhæng er imidlertid, at dette opråb ikke blev til på initiativ af dem, der ved deres navn kom til at stå for indholdet af det, men at det udgik fra en diskret propagandamyndighed i det tyske kejserrige.

I forhold til den slående offensive formulering "J'Accuse"... er vendingen "Es ist nicht wahr"... aldeles defensiv. Den søger at dementere nogle forhold eller nogle beskyldninger, som andre har rettet mod Tyskland og dets krigsmæssige fremfærd. - I sig selv er ethvert dementi af andres påstande eller angreb pr. definition udtryk for en forsvarsattitude. I det hele taget er det aldrig noget gunstigt udgangspunkt for en argumentation at begynde med en ikke-sætning. Det afslører både, at andre har sat dagsordenen, og at man ikke har magtet at bryde modpartens offensive argumenter og holdning. - Nok så meget ved denne formulering som ved de seks påstandes grove urimeligheder udstilledes dokumentets forbavsende klodsethed og stupiditet.

Clemenceaus iscenesættelse af Une protestation havde været yderst diskret, næsten umærkelig, mens instrumenteringen til gengæld er øredøvende 
i de 93 personligheders opråb. Der er en himmelråbende modsigelse mellem dokumentets primitive påstande i de seks punkter i forhold til det intellektuelle niveau, som de personligheder, der havde undertegnet urimelighederne, ellers var kendt for.

En forklaring på dette misforhold kunne være, at hensigten med opråbet mere var at skulle finde anvendelse på hjemmefronten end i det neutrale udland. De pågældende fremragende tyske personligheders navne har al berømmelse til trods nok haft større vægt i Tyskland end udenfor, og det kan have været lettere for et tysk publikum at acceptere de urimelige påstande i de seks så bombastisk dementerende sætninger, end for et udenlandsk, der også havde adgang til ententelandenes synspunkter $i$ piecelitteratur og presse. Dette forhold, sammenholdt med at den nationale ophidselse i Tyskland var betydelig i disse efterårsmåneder i 1914, kan være en forklaring på, at de pågældende 93 personligheder har kunnet bevæges til at sætte deres navn under disse påstande, hvis primitivitet, de i deres sjæls inderste ikke kan have været $i$ tvivl om. National ophidselse parret med en for unuanceret opfattelse af embedsmandens pligt over for fædrelandet kan være en forklaring på, at dette dokument overhovedet kunne komme i stand. Nogle af de underskrivende fortrød i øvrigt senere, at de havde sat deres navn under det papir.

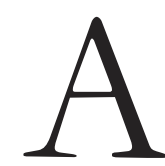
t opråbet hurtigt blev problematisk og opfattet som taktisk forfejlet i det ringeste i det neutrale udland, afsløres af en Bericht über die Presseverbältnisse und Pressebearbeitung in Dänemark, udarbejdet af professor für Landwirtschaft Anton Hollmann til brug for det tyske gesandtskab i København, ${ }^{5}$ og dateret den 25 . oktober 1914 , - blot små tre uger efter fremkomsten af de 93s opråb:

"Verfehlt waren die Publikationen in dänischer Sprache von privater Seite in Bändchen, Flugblättern, Aufrufen, Briefen und Aufsätzen einzelner und grösserer Gruppen. Sie haben nur Unwillen und Hohn, teilweise scharfe Ablehnung in der Presse hervorgerufen. So die Wabrbeit über den Krieg, die Publikationen des Bureaus des Handelstags, Aufrufe deutscher Theologen und Professoren". 6

Professor Hollmanns vurdering sigter ganske vist bredere end til det Aufruf..., de 93 havde udsendt, ligesom dette ej heller havde været fra privat side, sådan så det blot ud på overfladen, men også deres manifestation er dækket af Hollmanns karakteristik, der unægtelig havde sin gyldighed i Danmark. I Tyskland var det til gengæld vanskeligere for ikke at sige umuligt at trænge igennem krigsbegejstringen med den slags kølige synspunkter i 1914.

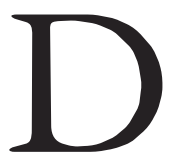
er var kun få i Tyskland, der fordømte krigen. En undtagelse udgjorde kredsen af intellektuelle i sammenslutningen Neues Vaterland, men denne sammenslutning blev bragt til tavshed i 1916. ${ }^{7}$ De fleste tyske krigsmodstandere tav, søgte enten det indre eller det ydre eksil, og det var derfor ret enestående, at den allerede da internationalt berømte fysiolog og 
læge, professor ved Berlins Universitet, Georg Friedrich Nicolai, i efteråret 1914 forfattede et modmanifest overfor de 93 personligheders opråb.

Georg Friedrich Nicolai var egentlig ikke pacifist ved krigsudbruddet, men til forskel fra sine lægelige kolleger var han ej heller reserveofficer, ligesom han som ungt menneske havde undgået den for studenter næsten obligatoriske indkaldelse som etårs frivillig. Han var ved krigens udbrud en nygift fyrretyveårig, placeret solidt og velhavende på samfundets mondæne side. Han lignede bestemt ikke en universitetsprofessor. Mensurarret, høgenæsen og den i højre øje arrogant fastklemte monokel gav ham snarere udseende af at tilhøre den prøjsiske officers- eller junkerstand. Intet kunne dog være mere misvisende. Oprindeligt hed Nicolai nemlig ikke Nicolai men Lewinstein, og han var jødisk, men som 24årig havde han ændret sit navn til det germansk klingende Nicolai, formentligt fordi han ikke ønskede, at hans jødiske baggrund skulle virke karrierehindrende for ham under de antisemitiske stemninger, der var en del af tidsånden i Tyskland omkring århundredskiftet. På trods af sin vilje til at assimilere sig yndede Georg Friedrich Nicolai alligevel ikke det militære establishment eller den tysk-prøjsiske militarisme. Han fandt den simpelthen idiotisk.

Ganske vist kunne han mobiliseres til landstormstropperne, men overfor læger blev dette kun sjældent praktiseret. Der var på den måde intet, der skulle have forhindret Georg Friedrich Nicolai i dels at nyde sit ægteskab,

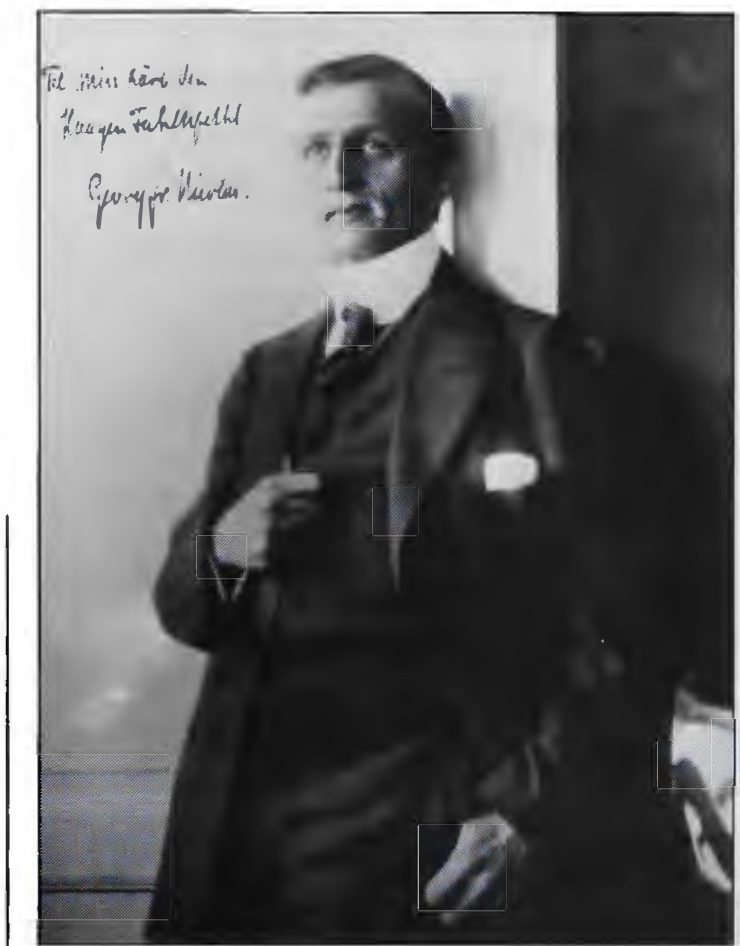

Georg Friedrich Nicolai (6.2.1874 - 8.10.1964). Efter Nicolais udseende at domme er billedet formentlig taget ca. 1914. Over hagen ses lige akkurat hans mensurar (Det Kongelige Bibliotek).

dels sit arbejde som hjertespecialist og søgt forelæser på Berlins Universitet på trods af krig og dyrtid. Alligevel ønskede han som god tysk patriot at yde sit og havde derfor undertegnet en civilkontrakt med de militære myndigheder, hvorefter han kom til at gøre tjeneste som civil cheflæge ved den hjertestation, der oprettedes ved Tempelhoflazarettet $\mathrm{i}$ Berlin. En stilling, der gjorde det muligt for ham at fortsætte sine forelæsninger og sin privatpraksis. Hans grundholdning var, at krigen ikke eksisterede for læger. Lægen fortsatte blot sin gerning, at lindre eller at helbrede og sætte lemlæstede mennesker sammen, nationalitet eller uniform ufortalt. ${ }^{8}$ I sit udgangspunkt var Georg Friedrich Nicolai bestemt ingen oprører eller samfunds- 
omstyrter; tværtimod var han nationalt sindet, men han fandt krigen uciviliseret, ude af takt med moderne udvikling, og han delte ikke den almindelige sejrsoptimisme i Tyskland.

\section{Efter hans opfattelse var} krigen i virkeligheden tabt efter Marneslaget, fordi Tyskland som aggressoren mistede fordelen af overraskelsesmomentet, da fronten størknede efter slaget. På samme måde, som en statistiker eller en økonom illustrerede han sin opfattelse af krigens fremtidsperspektiv $i$ et koordinatsystem, der i vandret plan viste en tidsdimension omfattende årene 1914-1918; i lodret en opgørelse af de samlede ressourcer, som henholdsvis centralmagterne og ententen kunne råde over. Med sin graf demonstrerede Nicolai $i$ to kurver, en for centralmagterne og en for ententelandene, sin opfattelse af forholdene. Kurven, der angav centralmagternes potentiale, begyndte for det første noget over ententens kurve og steg i en dristig, konveks linie i 191415 langt stejlere end ententelandenes, fordi Tyskland ved krigens begyndelse simpelthen var bedre forberedt på krig, militært og produktionsmæssigt. Ententelandenes kurve steg til gengæld konkavt i en langt blødere bue, men den vedblev at stige, fordi ententelandene rådede over større ressourcer, mens centralmagternes allerede begyndte at falde i løbet af 1916. Punktet, hvor centralmagternes nedadgående kurve og ententelandenes stigende skar hinanden, markerede for Nicolai det tidspunkt, hvor den sidste mulighed for at opnå en forståelsesfred med ententen fandtes. Ifølge Nicolais grafiske fremstilling ville denne situation opstå omtrent $\mathrm{i}$ juni 1918. Angiveligt sendte Nicolai sin advarende beregning i et brev til det store hovedkvarter lige efter Marneslaget på et tidspunkt, hvor sejrsjubelen i Tyskland var fuldstændig øredøvende. ${ }^{9}$

Hvorledes den allerhøjeste krigsherre og hans store generalstab måtte have modtaget den skeptiske professors beregninger, fortaber sig $i$ det uvisse. Ligeledes er det usikkert, om myndighederne allerede på dette tidspunkt blev opmærksom på Nicolai som en "besværlig person," der skulle observeres. Tilsyneladende skete det ikke, men da det blev kendt, at Nicolai havde forfattet et modmanifest vendt mod de 93 fremragende tyske videnskabsmænd og kulturpersonligheder, rettedes søgelyset mod ham.

Indtil den dag da Aufruf an die Kulturwelt forelå, havde Nicolai haft den bestemte forventning, at forskeren eller åndspersonligheden først og fremmest tjente sandheden. Aufruf an die Kulturwelt frigjorde ham endegyldigt fra den illusion, men provokerede ham til at forfatte et modmanifest af en helt anden visionær, moralsk lødighed, og i midten af oktober 1914 havde Nicolai udarbejdet sit manifest, der fik titlen Aufruf an die Europäer.

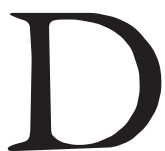
ette opråb tog udgangspunkt i det absurde paradoks, at moderne teknik og trafik på den ene side havde fort til en faktisk og praktisk anerkendelse af den store betydning som internationale forbindelser havde landene imellem, samtidig med at ingen krig førhen på så gennemgribende 
og konsekvent en måde havde afbrudt alt internationalt samarbejde og kulturelt fællesskab mellem de europæiske lande, som den nærværende krig.

Ud fra forskerens og kulturpersonlighedens kosmopolitiske arbejde, havde Nicolai forventet, at en fælles verdenskultur havde ligget forskere og kunstnere mere på sinde end andre, fordi netop sådanne grupperinger $\mathrm{i}$ højere grad end så mange andre var afhængige af et intensivt samkvem på tværs af grænserne. I stedet havde Nicolai oplevet, at videnskabelige og kulturelle miljøer i Tyskland havde ladet sig gribe af kampstemning og nationalt fædrelanderi i en hidtil uset grad og næsten udelukkende udtalt sig på en sådan måde, at det måtte opfattes, som om disse kredse på ingen måde fandt det ønskværdigt at genknytte de brudte forbindelser mellem landene. Denne situation fandt Nicolai var en ulykke for den europæiske kultur i videre forstand. Endelig var det hans opfattelse, at krigen ikke ville efterlade nogen sejrherre men kun besejrede, og følgelig var det vigtigt, at dannede mænd og kvinder $\mathrm{i}$ alle stater gjorde deres indflydelse gældende, for at fredsbetingelserne ikke skulle blive en kilde til fremtidige krige, men at fredsbestræbelserne derimod blev udgangspunkt for skabelsen af en organisk overstatslig enhed i Europa. De tekniske og intellektuelle forudsætninger herfor var til stede:

"Aber es ist notwendig, dass die Europäer erst einmal zusammenkommen, und wenn - was wir hoffen - sich genügend Europäer in Europa finden, d. h. Menschen, denen Europa nicht nur ein geographischer Begriff, sondern eine wichtige Herzenssache ist, so wollen wir versuchen, einen solchen Europäerbund zusammenzurufen. - Der soll dann sprechen und entscheiden. Wir selber wollen hierzu anregen und auffordern, und so bitten wir Sie falls Sie uns Gesinnungsgenosse und gleich uns entschlossen sind, dem europäischen Willen einen möglichst weitreichenden Widerhall zu verschaffen, Ihre Unterschrift zu senden."10

Oprindelig var Nicolai alene om sit opråb, som han i begyndelsen sendte til sin ven og kollega Albert Einstein, samt til den gamle astronimiprofessor, Wilhelm Förster. Denne havde ganske vist først underskrevet de 93s opråb, men havde siden bittert fortrudt, og han var derfor ivrig efter at markere en afstandtagen. Desuden satte Nicolais gode ven, forfatteren og oversætteren Otto Buek, sit navn under Aufruf an die Europäer, men hermed var det slut.

$\mathcal{T} \begin{aligned} & \text { icolai havde lovet sig meget } \\ & \text { af sit opråb og forventet, } \\ & \text { at det ville vække berettiget }\end{aligned}$ opsigt, men det kom ikke til at slå til på den måde, han havde tænkt sig. Ingen yderligere af de kolleger på Berlins Universitet, som han foreviste opråbet, vovede at skrive under, om end det ikke skortede på ivrige, tungefærdige sympatitilkendegivelser. Overfor den store offentlighed forblev Nicolais manifest ubekendt, men ikke for myndighederne. Efter han havde annonceret en forelæsningsrække på Berlins Universitet under titlen, "Der Krieg als biologischer Faktor in der menschlichen Evolution", forflyt- 
tede man Nicolai fra hans begunstigede stilling som leder af hjertestationen ved lazarettet $\mathrm{i}$ Tempelhof til den vestpreussiske fæstningsby Graudenz, hvor

Fritz Reuter havde siddet fængslet i det nittende århundredes første halvdel, og hvor der ud over Fritz Reuters celle, - der siden blev betragtet nærmest som et "nationalt Gedenkstätte", - nu fandtes et epidemi-lazaret, hvor Nicolai skulle gøre tjeneste. Forsættelsen skete rent administrativt, af tjenestlige grunde, som det hed, og der var således ingen "Nicolai-sag" på overfladen. Nicolai kunne dog have undgået forsættelsen, hvis han havde været indstillet på at stoppe sine forelæsninger, men det var han netop ikke, og følgen blev, at han kort og godt måtte melde sig til tjeneste i Graudenz.

Epidemibekæmpelse var ikke Nicolais speciale, hvilket han højrøstet gjorde opmærksom på, og der gik derfor ikke lang tid, før stedets kommandant fornuftigt nok udnævnte ham til rådgivende læge for hjertesygdomme ved det 17. Armékorps, hvilket var en stilling, der både gav bevægelsesfrihed og kompetence. Nicolai indrettede sig, gik på jagt med kommandanten og red lange ture i omegnen af Graudenz; hans nye forhold var ikke tjenestligt krævende, men de gav ham god anledning til refleksion, og han begyndte at bearbejde sit materiale fra de strandede forelæsninger til den bog, der siden skulle blive til Die Biologie des Krieges.

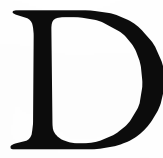
en 7. maj 1915 blev den engelske passagerdamper Lusitania sænket, en krigshandling, der også ramte det neutrale U.S.A. hårdt, idet et stort antal amerikanske borgere omkom. I Tyskland var den umiddelbare virkning derimod højrøstet skadefryd. Under et middagselskab på Hotel Königlicher Hofi Graudenz tilkendegav Nicolai på yderst uforbeholden måde sin mening både om sænkningen af det engelske passagerskib og om den tyske krigsførelse i det hele taget. Hans meninger havde været stærkt afvigende fra dem, der ellers blev luftet ved den lejlighed, og hans sidemand ved bordet følte sig foranlediget til at anmelde ham til kommandanten for at have udtrykt unationale meninger.

Sagen var ikke velkommen for den pragmatiske kommandant eller for myndighederne i øvrigt. Den var

Lusitania i New Yorks havn, september 1907 på sin jomfrurejse fra London. I maj 1915 krydsede skibet Atlanterhavet for 202. gang, for at blive sanket af en tysk u-båd ved Irlands kyst 7. maj. Ialt omkom 1.198 personer. I oktober samme år gav Tyskland en officiel undskyldning for bandelsen.

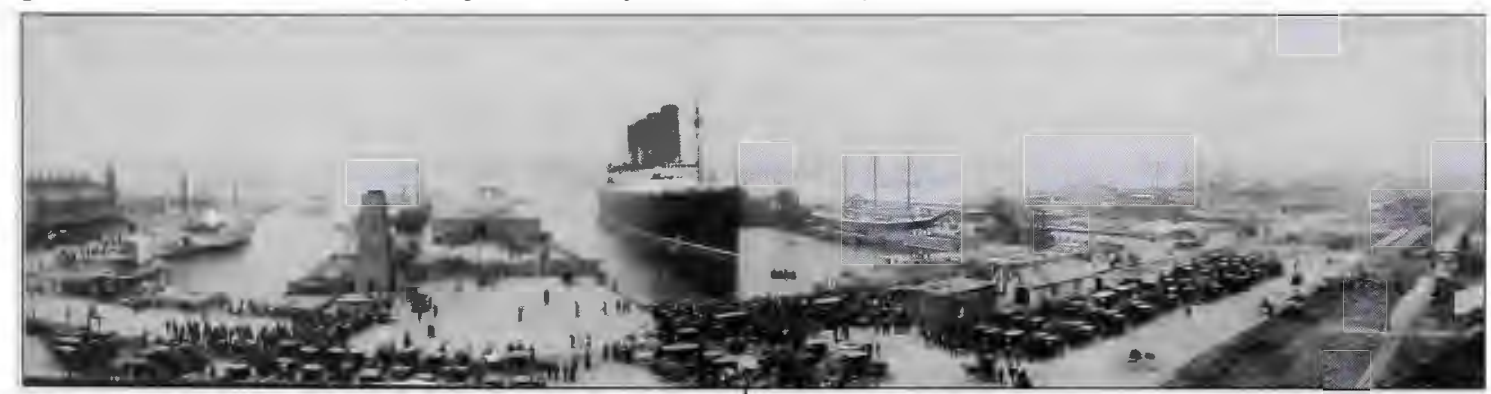


vanskelig at håndtere på diskret måde. Nicolai havde jo en civil kontrakt med hæren men var netop ikke underlagt militær straffelov, og følgelig kunne man ikke uden videre idømme ham nogen disciplinærstraf for hans åbenmundethed. Igen forsøgte man sig med en administrativ forflyttelse, denne gang til en lejr for russiske krigsfanger i det gudsforladte Tuchel i Vestpreussen.

Nicolai var dog ikke sindet uden videre at bøje sig for denne nye forsættelse. Han forlangte, at man rejste en disciplinærsag imod ham. Det skete naturligvis ikke, fordi det med al tydelighed ville have afsløret ulovligheden i det militære bureaukratis fremfærd. Sluttelig klagede Nicolai til kejseren selv, og han overførtes til Danzig, hvor hans foresatte til gengæld krævede, at han aflagde faneed og afholdt sig fra enhver politisk ytring. Nicolai afviste disse fordringer med henvisning til, at han som civilt ansat ikke kunne pålægges hverken at aflægge faneed eller påbydes ytringsforbud. Efter denne sidste omgang var det ude med det militære apparats tålmodighed, man skar igennem: Indkaldte Nicolai som menig til Landstormen og befalede ham at melde sig til tjeneste som menig sygehjælper i fæstningslazarettets laboratorium hos chefen, en $\mathrm{dr}$. Schwer. Dette blev ikke enden for professor Nicolai, men derimod enden på begyndelsen af Nicolai-affæren. Som sygehjælper med kontortjeneste fik Nicolai gjort Die Biologie des Krieges færdig. Problemet var herefter at få den publiceret. Nicolai havde skrevet sin bog for et tysk publikum, han opfattede den som en patriotisk samvittighedshandling overfor Tyskland. Der var kun én ting i vejen: Den tyske regering delte ikke hans opfattelse af begrebet patriotisme. Så godt som alle de forlæggere, Nicolai forsøgte at få til at tage bogen, afviste at sætte penge i dens udgivelse, eftersom det var fuldstændig sikkert, at dette værk ville blive beslaglagt i samme øjeblik, det blev lagt frem på boghandlerdisken. Sluttelig var det dog lykkedes Nicolai at overtale sin ven, Curt Thesing, der udover at dele Nicolais anskuelser, også var ejer af et naturvidenskabeligt forlag i Leipzig, til at tage bogen på forlag, men politiet var velunderrettet $\mathrm{og}$ så ihærdigt, at det nåede at beslaglægge de første to hundrede sider, man havde nået at trykke. Nicolai måtte tilbringe en nat i fængsel, og forlæggeren fik en kraftig advarsel mod at lade bogen udkomme. Enden på sagen blev, at Die Biologie des Krieges udkom i Schweiz på Orell Füsslis forlag i 1917.

På dette tidspunkt var Nicolai indkaldt til militærtjeneste ved Landstormen og var underlagt skriveforbud. Han kunne dog afvise enhver beskyldning om at have ladet manuskriptet smugle til Schweiz for at lade det udkomme hos Füssli. Nicolais bog blev tilsyneladende trykt uden hans aktive medvirken, men angiveligt havde han forud ladet forskellige kopier af manuskriptet cirkulere diskret i Tyskland, og en af disse manuskriptkopier var blevet bragt til Schweiz, antagelig som diplomatisk kurerpost af Leonhard Frank, muligvis uden Nicolais vidende. ${ }^{11} \mathrm{Da}$ bogen udkom i Schweiz, vakte den betydelig opsigt, navnlig indenfor den internationale fredsbe- 
Romain Rolland, $i$ flere benseender en fransk parallel til Nicolai. Han var pacifist, og udgav 1914 i protest med verdenskrigen Au-dessus de la Mêlée (Over Kampen).

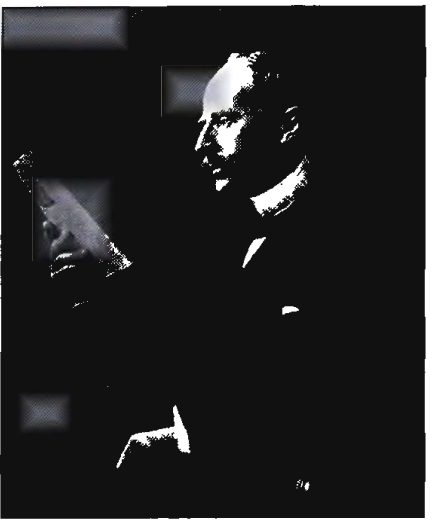

vægelse, og den blev anmeldt med beundring og begejstring, bl.a. af Romain Rolland, der som franskmand befandt sig $i$ en lignende position overfor de franske myndigheder som Nicolai overfor de tyske; men med den afgørende forskel, at Romain Rolland var i eksil i Schweiz og dermed udenfor de franske myndigheders rækkevidde. ${ }^{12}$

Efter at have passet sin tjeneste som sygepasser $i$ to år, indtraf der endnu en chikanøs ordre til Nicolai: han skulle overføres til et andet kompagni og uddannes til våbentjeneste. Han nægtede dette, men herefter var der kun to muligheder for ham, og som det hedder $i$ de islandske sagaer: Ingen af dem var gode. Nicolai kunne enten gå i fængsel eller flygte ud af Tyskland til et af de tre neutrale nabolande, Schweiz, Holland eller Danmark. Efter et forgæves forsøg på at gå over grænsen til Schweiz, valgte Nicolai i stedet at flygte til Danmark. Det lykkedes ham at komme i forbindelse med tre formående, spartakistisk sindede flyvere i det tyske luftvåben, der havde planer om at absentere sig, og $\mathrm{i}$ to ældre skolemaskiner, en F 16 og en Albatros, lykkedes det dem at nå Danmark. Nicolai og hans pilot landede uden vanskelighed $i$ Vigerslev ved Valby Gasværk, mens det andet fly måtte gå ned på Langeland.

Det siger sig selv, at Nicolais og hans tre ledsageres bratte entré i Danmark 20. juni 1918 måtte vække opmærksomhed. Indtil dette tidspunkt havde man ikke modtaget desertører eller spioner fra luften. Nicolai var ganske vist hverken desertør eller spion, selv om hans junkeragtige udseende $i$ begyndelsen ledte til en sådan misopfattelse, og til en indledning søgte det danske politi med flid at hemmeligholde den mondæne flygtnings opholdssted i dagene umiddelbart efter landingen, hvilket var til ualmindelig fornøjelse specielt for Politiken, der den 26. juni havde opsporet Nicolai og bragt et interview med ham.

\section{Selv opfattede Nicolai sig} ikke som desertør, men henholdt sig til sin civilkontrakt med de tyske militære myndigheder, hvorfor han ikke kunne være underlagt militær strafferet. Derimod var hans tre spartakistiske ledsagere desertører, og følgelig blev Nicolai af de danske medier og de danske myndigheder i begyndelsen opfattet på samme måde, hvilket blev lagt ham til last, $\mathrm{da}$ han vendte tilbage til Tyskland.

Under interviewet var Nicolai blevet spurgt, om han havde truffet Georg Brandes, hvilket han havde måttet svare benægtende på, men samtidig ytrede han ønske om at mødes med Brandes, hvis navn han kendte i forvejen. Hvad Georg Brandes angik, var også han bekendt med Nicolais skæbne i Tyskland, idet han havde omtalt ham og Die Biologie des Krieges i sit forord til 


\section{POLITLKN}

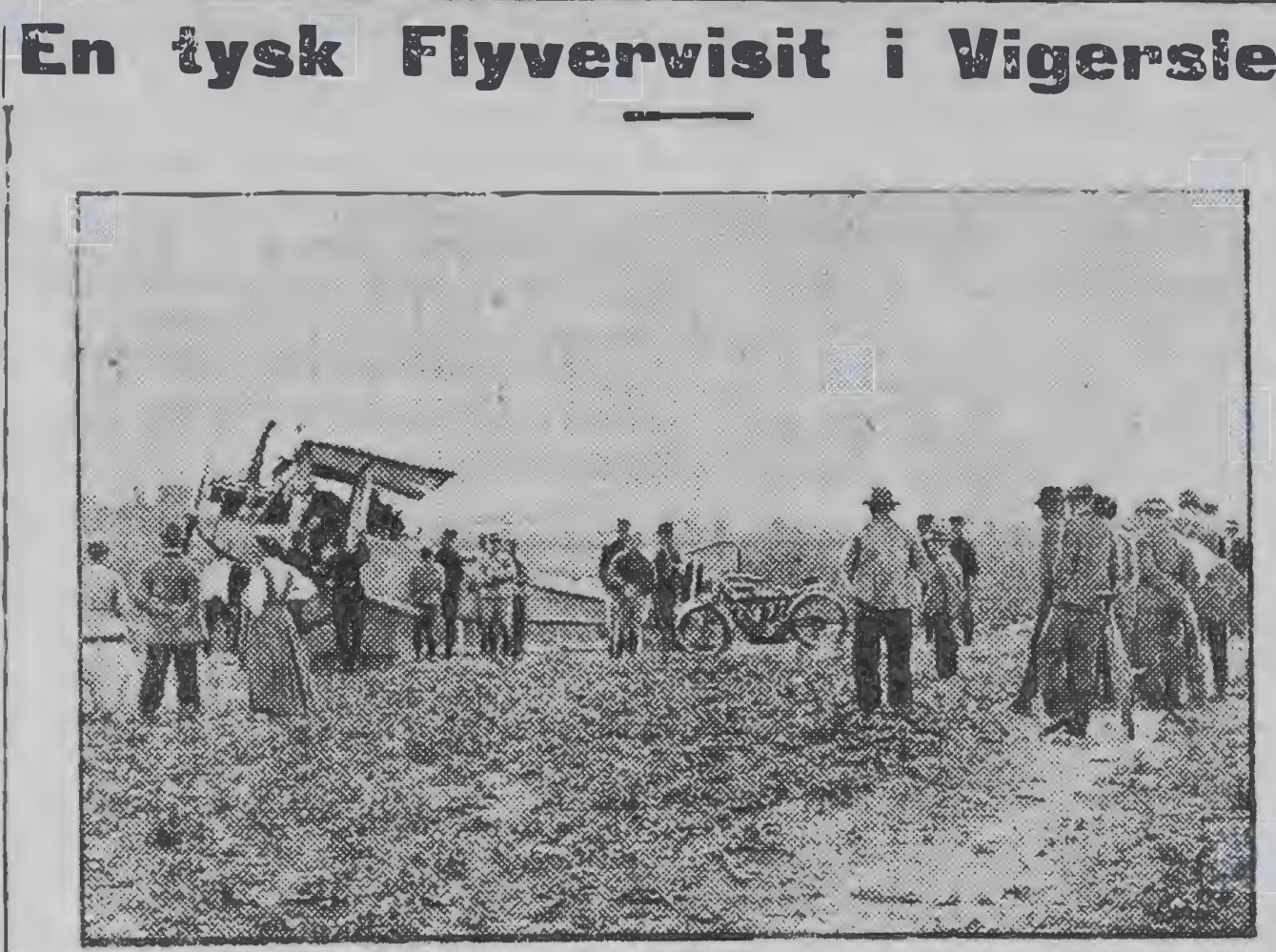

Wen tyske Albatroj-fyvemaskine, der i Mar landede red Vigerslev Gas: rer.

En stor tyok Flyremaskine landede i Gaar Mlorges i Nærheden af Gasværket i Vigerslev. Dens to Passagerer, hvis Navn og Hjemsted hemmeligholdes, blev som tyste Desertorer taget i Forvaring af Politiet, bvilket blandt andet medførte, at de i Nat har sovet i Nytorvs Arrest

Maskinen bler i Garr taget i Øjesyn af en Mængde Mennesker. Flere Fotografer, der forsøgte at tage et Billede af den, fik, uvist af hvilken Grund, deres Apparater konfiskeret af Militæret. Vor Fotograf, der havde taget Opstilling $\mathrm{i}$ en Kolonihave, undgik heldigt at komme $\mathrm{i}$ Konflikt med Myndighederne og bragte os ovenstaaende vellykkede Billede.

Nicolais fyvemaskine i Vigerslev (Politiken 21. 6. 1914)-Den ironisk-maliciose billedtekst var typisk for Politikens reportager om politiets forbold til Nicolai og de ovrige flygtninge (Det Kongelige Bibliotek).

den danske udgave af E. D. Morels skrift $\mid$ april 1918 i København. ${ }^{13}$ Men allereCzarismen og Krigen, der var udkommet i de 22. juni, blot to dage efter Nicolais 
bemærkelsesværdige flugt, blev Brandes gjort opmærksom på, at en af de luftbårne flygtninge havde været Nicolai, hvilket han noterede sig i sin dagbog på denne måde: "Derefter Melnik om G. Nikolais Ankomst, hans Flugt for ej at blive til menig Soldat."14 Den 27. juni 1918, samme dag, som interviewet havde været i Politiken, fulgte han op på sin indledende bemærkning med disse ord om Nicolais ønske om at møde sig:

"Melnik beder fra Nicolai, om han maa komme. Han har i Politiken idag udtalt $\varnothing$ nsket at faa mig at se og kaldte mig en af vor Tids interessanteste Personligheder."15

Det interessante ved Brandes' notits i dagbogen er dog ikke besøget eller den smigrende karakteristik, men den fortaler for Nicolai, som er anført i dagbogen.

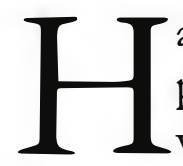

ans fulde navn var Josef - eller på russik Ossip - Melnik. Han var russisk jøde, men havde siden begyndelsen af 1900-tallet opholdt sig i Tyskland; desuden havde han tætte forbindelser til Danmark. Siden 1905 havde han været en god ven af Herman Bang og blev via ham også ven med Gyldendals direktør, digteren Peter Nansen og siden med Georg Brandes. Som Presseberater for den tyske Hamburg-Amerika Linie havde Melnik i 1912 skaffet Herman Bang overfart til New York på den rejse, der skulle blive hans sidste. Og i forsommeren 1914 havde Melnik inviteret Georg Brandes, filmstjernen Asta Nielsen og hendes mand Urban Gad til at deltage i atlanterhavslineren Vaterlands jomfrurejse til New

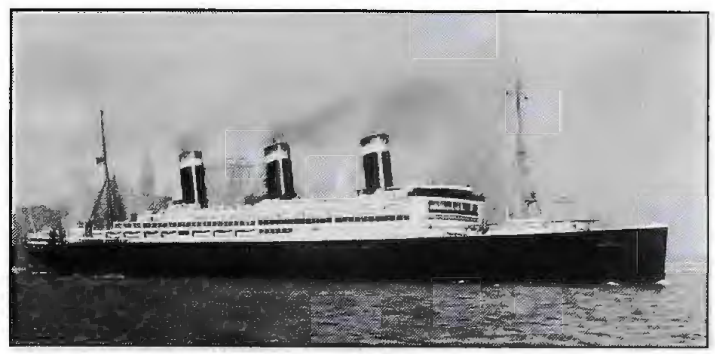

Vaterland i New Yorks bavn. Skibet bragte 1914 Georg Brandes, Asta Nielsen og Urban Gad til Amerika.

York, en tur, Georg Brandes havde nydt fuldt ud, og som også som foredragsturné havde været ganske indbringende for ham. ${ }^{16}$ Georg Brandes havde kendt Melnik siden 1905, hvor han havde introduceret sig hos ham med henvisning til Herman Bang. ${ }^{17}$

I løbet af krigsårene sås Georg Brandes og Melnik hyppigt til frokoster hos Georg Brandes, ligesom Brandes også enkelte gange besøgte Melnik, og han fungerede i høj grad som informant og modspiller for Georg Brandes, når det gjaldt krigen og dens gang. Han var forbavsende velunderrettet om, hvad der foregik i Rusland og i Tyskland, idet han navnlig i det første krigsår var i stand til at rejse uhindret mellem St. Petersborg og Berlin med København som mellemstation. ${ }^{18}$ Ved et par lejligheder havde Georg Brandes dog noteret, at Melnik forekom ham meget tyskvenlig, men ikke desto mindre viser dagbogen, at Brandes lagde vægt på at mødes med Melnik; han omtales således aldrig som et fredsforstyrrende moment, hvilket ellers var tilfældet med de fleste af dem, der opsøgte Georg Brandes.

Brandes har imidlertid næppe været på det rene med, at Mel- 
nik egentlig var tysk agent, og at han personligt var nært knyttet til det tyske kejserriges gesandt i Danmark Ulrich Graf von Brockdorff-Rantzau. ${ }^{19}$ På den tid, da Nicolai landede i København, så det ganske vist ud til, at forholdet mellem gesandten og hans agent var mindre heldigt. Sagen var, at Melnik var blevet afskediget fra sin stilling som pressemedarbejder ved gesandtskabet allerede pr. 1. april $1918,{ }^{20}$ men alligevel ser det ud til at han stadig havde forbindelse til gesandten efter dette tidspunkt. I sit dagbogsnotat fra den 22. juni 1918 omtaler Georg Brandes i forbindelse med bemærkningerne om Nicolai, at Melnik overfor ham havde klaget over Brockdorff-Rantzaus behandling af ham; gesandten skulle have hindret Melnik i at få pas til Rusland, ladet ham angribe i Politiken og ligeledes forhindret, at han fik indrejsetilladelse til Tyskland. Hvad Melnik næppe er blevet oplyst om af Brockdorff-Rantzau, var, at kilden til den modvilje, der ramte ham, sandsynligvis var at finde hos de militære myndigheder i Tyskland på det tidspunkt, formentlig affødt af netop hans forbindelse i København med flygtningen Nicolai, der var landet på neutralt område i et stjålet militærfly. ${ }^{21}$ Til syvende og sidst er det dog umuligt at vide, om Melniks bemærkninger om sine besværligheder har bundet i dette forhold, eller om de blot har været på skrømt for at sløre hans forbindelse til gesandtskabet overfor Brandes.

Zuelzer nævner, at Nicolai ved sin ankomst til København meget korrekt havde opsøgt Brockdorff-Rantzau i gesandtskabet, men denne havde kun talt høfligt og distant uforbindende med ham, hvilket havde givet Nicolai indtryk af, at gesandten ikke syntes at have interesseret sig synderligt for hans person eller ophold i København. ${ }^{22}$ Formentligt har der været tale om et synsbedrag; man tager ikke nødvendigvis fejl, hvis det antages, at Brockdorff-Rantzau via Josef Melnik i høj grad har næret ønske om at kunne følge med i Nicolais københavnske aktiviteter for om muligt at kunne stække dem, hvis synlighed og hørbarhed skulle tage overhånd. Det har næppe været nogen tilfældighed, at netop Melnik blev den person, der introducerede Nicolai for Georg Brandes. Der var nemlig den ekstra pointe, at Melnik og Nicolai kendte hinanden i forvejen. Efter Brandes i det tidlige forår 1918 havde skrevet sit forord til E. D. Morels skrift Czarismen og Krigen, hvor han som nævnt havde omtalt Nicolai, havde Melnik efterfølgende spurgt i et brev til Brandes, om Nicolai også hed Georg Friedrich; hvis det var tilfældet, var Melnik udmærket kendt med ham, thi da var han:

“... ein lieber Jugendfreund von mir. Wir haben gemeinsam in Heidelberg studiert (er war Mediziner) und später viel verkehrt. Ein vorzüglicher Mensch und enorm begabter Intellekt. Er offenbarte schon damals starke kulturpolitische Interessen und Instinkte, hatte ausgezeichnet Russisch gelernt und stach deutlich von den üblichen deutschen 'Gelehrten' ab... “23

En lille måned efter Nicolais ankomst til København, den 20. juli 1918, noterede Georg Brandes i sin dagbog, at han havde været til frokost 
hos Brockdorff-Rantzau, og at samtalen mellem dem havde drejet sig om Melnik og Nicolai. "Vi enige" sluttede Brandes sin bemærkning om frokosten uden dog at specificere, hvad enigheden havde gået ud på. ${ }^{24}$ Formentligt har gesandten lagt lige dele afstand til sin "Vertrauensmann" og til flygtningen Nicolai, den sidste har han, - når man kender Brockdorff-Rantzaus evner som manipulator, ${ }^{25}$ - antagelig søgt at fremstille som en urealistisk fantast. Lige så lidt - eller måske snarere langt mindre - har Nicolai som nyankommet til København været i stand til at gennemskue, at Melnik sandsynligvis i højere grad har været repræsentant for det tyske gesandtskab end for den danske berømthed, hos hvem han så velvilligt havde banet vej:

"Hochverehreter, lieber

Freund, Nicolai möchte gern Ihnen vorgestellt werden. Könnten Sie uns nächsten Sonnabend (übermorgen) empfangen? Und um welche Zeit? Damit Sie ihn (sic!) voraus ein wenig über ihn orientiert sind: er war Professor an der Berliner Universität, sein in der Schweiz erschienenes Buch besteht aus Vorlesungen die er ursprünglich an der Universität - für Hörer aller Fakultäten - gehalten. Da die Vorlesungen begeisterte Aufnahme gefunden und die Erwartungen der Behörden enttäuscht hatten, musste er sie einstellen. Nach dem Erscheinen seines Werkes wurde er zu einer Disziplinarstrafe (4 Monate Gefängnis) verurteilt, ohne sie jedoch abbüssen zu müssen. Zuletzt sollte er als gewöhnlicher Soldat (als gemeiner) nach der Front geschickt werden, was nach Ansicht hervorragender Juristen
Georg Brandes, som Nicolai var meget ivrig for at fä kontakt med $i$ Kobenhavn (Det Kongelige Bibliotek).

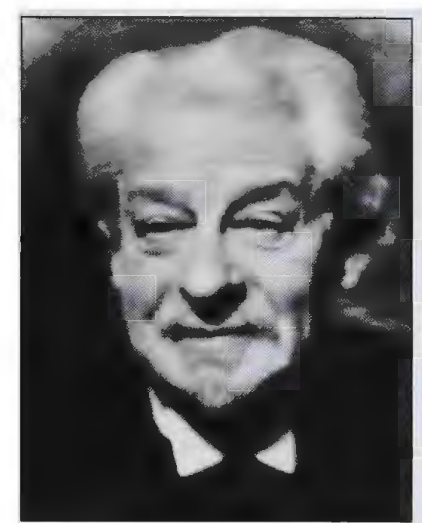

widerrechtlich ist. Dies war ein mitbestimmender Grund für seinen Flug nach Dänemark. - Wie er mir mehrmals betraute, freut er sich ausserordentlich, Ihre persönliche Bekanntschaft machen zu dürfen. Ihre Schriften kennt er ausgezeichnet. Auf Wiedersehen Ihr Ihnen ergebener Melnik." 26

Nicolais ønske om at møde Georg Brandes var ikke begrundet i nysgerrighed, men han havde sine planer, og Georg Brandes var en væsentlig del af dem.

I sporet efter sit i Tyskland mislykkede Aufruf an die Europäer havde han til hensigt med København som base at skabe en art europæisk fredsbevægelse, hvor han til en begyndelse agtede at lade en kreds af berømte europæiske intellektuelle tegne et nyt samvirke for fred og samarbejde mellem de europxiske lande med navn og helst også med deres medarbejderskab. Hans vision var, at et sådant samarbejde på længere sigt kunne føre til en form for overstatslig organisation i Europa. Det var intet mindre end en virkeliggørelse af de tanker, Nicolai først havde givet udtryk for i sit Aufruf an die Europäer fra 1914, men denne gang skulle det ikke 
blot være et enkeltstående åbent brev, men et periodisk skrift, der $\mathrm{i}$ et videre perspektiv skulle virke samlende og organiserende på en europæisk bevægelse. Formentlig har Nicolai allerede ved den første sammenkomst med Georg Brandes givet udtryk for sine planer; i alt fald havde han ment, at der ville blive revolution i Tyskland:

"G. F. Nicolai her med Melnik blev 3 - 6. livlig Mand, godt Hoved, forhærdet Optimist. Troer paa Revolution i Tyskland efter Krigen, hans Skrifter kommer. I øjeblikket er Militæret alt, Kejser og Rigskansler intet, Hindenburg og Ludendorf afgør det hele."27

Kontakten var skabt, og blot to dage senere kunne Brandes notere, at "Nicolai havde været henrykt for sin visit hos Edvard og mig og nogle flere."28 Takket være Brandes' notits kan man se, at Nicolai ikke har ligget på den lade side. Øjensynligt har han været stærkt optaget af at skabe sig et intellektuelt netværk under sit exil i København.

Den Edvard, der omtales i dagbogen, var selvsagt Edvard Brandes.

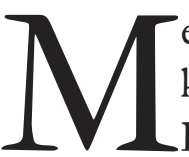
en efter Georg Brandes' frokostmøde med BrockdorffRantzau den 20. juli og i tiden derefter blev Georg Brandes imidlertid mere og mere forbeholden overfor Nicolai, der på sin side med iver søgte at involvere ham. Brandes følte disse engageringsforsøg som plageri, og efterhånden så han også med stærkt kritiske øjne på Nicolai. Som det var hans sædvane, var han klogt tilbageholdende med at involvere sig selv og sit navn. I en no- tits i sin dagbog fra 1. september 1918, hvor han synes at tage datteren Ediths indtryk til sig, mente han ligefrem, at Nicolai var lidt gal, led af højhedsvanvid og nærede had til Tyskland. ${ }^{29}$ Men Nicolai var ikke nem at afvise, hvilket et brev fra ham af 23. september 1918 med al tydelighed viser:

"Hochverehrter Herr Bran-

des! In 8 Tagen wird die erste Nummer des 'Werdende Europa', von deren ich Ihnen ja neulich sprach, erscheinen. Von Skandinaviern wollen Svante Arrhenius, Ellen Key, Gerhard Gran, Carl Lindhagen, Prof. Albr. [skal være Kristoffer] Nyrop und Sophus Michaëlis sie als Mitherausgeber zeichnen. Ich wollte Sie nun nochmals fragen ob Sie mir erlauben - was Sie mir ja schon halb und halb versprochen haben - Ihren Namen als den bekanntesten Europäers in Skandinavien an deren Spitze zu stellen. Ich wäre Ihnen sehr dankbar, wenn Sie mir Ihre definitive Antwort möglichst bald mitteilen würden, denn wie gesagt die erste Nummer erscheint jetzt. Die Zusammenkunft von Wells, Romain-Rolland und Maxim Gorki hat Aussicht sich zu realisieren. Ich habe sie in Ihrem Namen geschrieben".... ${ }^{30}$

Det fremgår således, at Nicolai ved at nævne Brandes' navn overfor Gorki, Wells og Romain Rolland har taget forskud på et tilsagn fra Brandes om at medvirke sammen med de øvrige skandinaver, men Brandes endte med at give sit endelige tilsagn, idet hans navn står på titelbladet af Das Werdende Europa Blätter für zukunftsfrobe Menschen, som bladet kom til at hedde. 
$\mathrm{T}$ idsskriftet skulle være neutralt overfor de krigsførende lande og: ..."leidenschaftlich Partei ergreifend für das Recht gegen die Macht." Ud over de i brevet til Georg Brandes nævnte personligheder fik tidsskriftet også tilslutning fra de berømte nordmænd Christian L. Lange og Fridtjof Nansen, mens det krigsførende ØstrigUngarn blev repræsenteret af Alfred Fried og Kurt von Reden. De var forståeligt nok begge i exil henholdsvis i Bern og København.

Der stod således et vigtigt internationalt netværk bag Nicolais tidsskrift, som skulle bidrage til at give foretagendet vægt. Ansvarshavende redaktør blev forfatteren og bankmanden Axel Valentiner, i hvis hus i Tisvilde Nicolai havde fået ophold.

\section{Det er usikkert, om Das}

Werdende Europa udkom 1. oktober 1918, eller om det først skete den 15., idet sidstnævnte dato figurerer på omslaget, mens den 1. oktober er angivet som udgivelsesdag på titelbladet. Bibliografisk er det ligeledes bemærkelsesværdigt, at Axel Valentiner står som redaktør på titelbladet af det eksemplar, der findes i Det Kongelige Bibliotek, mens Zuelzer i sin bog om Nicolai nævner ham selv som redaktør. ${ }^{31}$ Zuelzer nævner videre, at Das werdende Europa kun udkom med dette første nummer, og at tidsskriftet ikke blev videreført. Imidlertid kan det konstateres, at der også udkom en dansksproget version med titlen Det nye Europa den 15. oktober. Denne danske udgave havde ikke Valentiner som ansvarlig redaktør. I stedet figurerer den $\mathrm{i}$ tiden kendte digter og journa- list Svend Borberg i denne egenskab. Bemærkelsesværdigt er det desuden, at der nåede at udkomme to numre af den dansksprogede version. Meget symbolsk udkom nr. 2 af Det nye Europa på våbenstilstandsdagen den 11.11.1918. Både den tyske og den danske version af tidsskriftet synes at være bibliografiske sjældenheder. ${ }^{32}$ For begge tidsskrifter var der dog fælles adresse: Skt. Jacobsgade 14. 2. sal, hvor Svend Borberg kunne træffes tirsdag og fredag mellem kl. 15.00 og 17.00, hvilket peger på, at han også har haft en hånd med i redaktionen af den tysksprogede udgave, Valentiner har måske blot været stråmand.

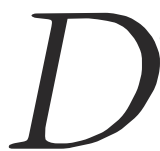
as werdende Europa var beregnet for den internationale læseverden, eller i det ringeste den tysktalende del af denne, og tidsskriftet sendtes til Schweiz i dette øjemed, eftersom det på forhånd måtte antages, at det ville blive forbudt i Tyskland og Østrig-Ungarn. Imidlertid viste det sig, at Nicolais tidsskrift så at sige blev kompromitteret på forhånd, idet den berømte schweiziske pacifist professor Ottfried Nippold ved en fejltagelse havde overladt det berygtede forlag Der freie Verlag i Bern et eksemplar af Nicolais artikel. Det var velkendt, at dette forlag var styret af tyske emigranter, der havde taget imod midler fra ententelandenes side, hvorfor forlaget og dets skribenter på forhånd var miskrediteret i Tyskland. ${ }^{33}$ Selv om Nicolai protesterede, nyttede det ikke. Han var mere eller mindre kompromitteret både $i$ ententens og centralmagternes øjne. 
Hertil kom, at Nicolai under sit københavnsophold var blevet opsøgt af et par tilsyneladende repræsentanter fra det franske gesandtskab i København, der angiveligt ønskede at sondere muligheden for en fransk udgave af Die Biologie des Krieges. De begik dog den påfaldende klodsethed åbenlyst at tilbyde ham en anselig sum for denne oversættelse, Nicolai gennemskuede følgelig dette propagandaforsøg og skal have afvist tilbudet. Også fra sovjetrussisk side forsøgte man at slå propagandamæssig mønt af Nicolais flugt til København og af hans placering som ny, international berømt pacifist, idet Sovjetunionen i det schweiziske propagandablad Nouvelle de Russie ${ }^{34}$ offentliggjorde, at man pr. 30. september 1918 havde givet Nicolai borgerrettigheder i Sovjetunionen. Temmelig absurd al den stund, Nicolai ingen sympati havde for revolutionen $i$ Rusland. Nicolai nærende bestemt ingen kommunistiske sympatier, hans holdninger var helt igennem borgerlige, og $\mathrm{i}$ almindelighed fandt han ikke verden - og i særdeleshed ikke Rusland - modent til socialismen.

Meget hurtigt kom Nicolai således i berøring med intellektuelle danske kredse, og for den sags skyld også indirekte med det tyske gesandtskab via Josef Melnik.

\section{Hasselbalchs Forlag, der} udover at have Det nye Europa og Das werdende Europa i kommission, viste desuden interesse for at udgive en dansk oversættelse af Die Biologie des Krieges, og dermed var vejen banet for en dansk udgave af den berømte bog. Oversætteren synes også hurtigt at være blevet fundet. Det blev Svend Borberg, der påtog sig opgaven, mens det lykkedes Nicolai at formå den modstræbende Georg Brandes til at skrive et meget udførligt forord til bogen, der endte med at blive nærmest en afhandling i sig selv. Den blev siden medtaget $\mathrm{i}$ hans essaysamling, Fredsslutningen. Tragediens anden Del, Kbh. 1919.35

Nicolais ønske - eller måske snarere fordring - på et forord til Krigens Biologi kom uhyre ubelejligt for Georg Brandes, der var stærkt optaget af at færdiggøre sin biografi, Julius Casar, og i sin dagbog gav han gentagne gange udtryk for stærk irritation og modvilje mod Nicolai og mod hans bog, som han ganske vist fandt dygtigt udført, men som ikke desto mindre kedede ham. ${ }^{36}$ Omkring den 26. oktober lykkedes det ham at afslutte arbejdet, og forordet blev sendt til Nicolai, der dog ikke var tilfreds. I et udførligt brev til Georg Brandes fra samme dag udtalte Nicolai på den ene side stor anerkendelse for tendensen i Brandes' forord, men dybest set har han ikke brudt sig om den. Brandes havde nemlig taget spørgsmålet om sænkningen af Lusitania op igen og havde bl.a. påvist, at skibet havde været opført i flådelisterne som engelsk hjælpekrydser, ligesom han også fremkom med en række argumenter, der bestemt ikke undskyldte sænkningen af lineren, men forklarede den som et resultat af ulykkelige omstændigheder frembragt af krigen og dens væen. Herved kom han indirekte til at virke som apologet for den tyske krigshandling overfor den engelske passagerdamper. I sit brev afviste Nicolai pure 
Brandes argumentation med påstanden om, at han havde misforstået ham, og i stedet optog han en ordrig og rethaverisk polemik mod Brandes, hvor han søgte at påvise, at sænkningen og den tyske u-bådskrigsførelse havde været imod folkeretten. ${ }^{37}$ Brandes optog Nicolais indvendinger med betydelig irritation, og i dagbogen for den 26. oktober skrev han: "Brev fra Nicolai med Indvendinger mod Forordet, højlig irriteret derover."38 Alligevel må han i et vist omfang have føjet Nicolai, for den 8. november 1918 kunne han afslutte sagen med denne mere positive bemærkning: Rettet og skrevet Forordet til Nicolai blev ganske godt; ret morsomt og lærerigt."39

Det ses således, at Nicolai under sit ophold i København, nok fandt et refugium, hvor han kunne være i fred for de tyske myndigheders chikane, og hvor han kunne arbejde for sin sag.

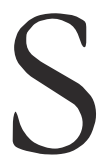
pørgsmålet er imidlertid, om ikke han i virkeligheden blev kompromitteret og stækket langt mere alvorligt i sit danske exil, end det havde været muligt for de militære myndigheder i Tyskland. Et fortryk af Nicolais artikel fra Das Werdende Europa nr. 1, Warum ich aus Deutschland ging offener Brief an den jenigen Unbekannten der die Macht hat in Deutschland kom ad veje, som - ifølge Zuelzer, - var uforklarlige for Nicolai, til England, endnu før det første nummer af Das Werdende Europa havde set dagens lys. ${ }^{40}$ Denne utidige publicering i England kom til at skade Nicolai alvorligt ikke mindst efter hans tilbagevenden til Tyskland, og det blev anledning til beskyldninger imod ham for at have gået englændernes ærinde i krigsårene.

Det forhold, at Warum ich aus

Deutschland ging... kunne læses i England, før dette åbne brev blev publiceret i Nicolais egne tidsskrifter, er kun tilsyneladende en ejendommelighed. En notits i Georg Brandes dagbog for den 5. oktober 1918 giver formentlig den naturlige forklaringen på fænomenet:

"Nicolai sælger sit dumme Brev til Times for 600 Pund, medens Hasselbalch havde udvirket 1200 for ham. Han er skør." 41

Det tyder på, at Nicolai selv har været kilden til den mistillid og misreputation, der ramte ham i Tyskland efter han var vendt hjem. Hvis Nicolai virkelig har solgt sit brev, sådan som Brandes mente, må han have været blind for, at netop en sådan handling ville stemple ham som englændernes mand. Ejendommeligt nok synes Brandes ikke at have haft øje for dette aspekt af Nicolais handel, han syntes blot, at Nicolai havde gjort en skidt forretning.

Der har næppe stået andre bag den aktion, om end Nikolai var "omgivet af agenter" med forbindelse til det tyske gesandtskab, der selvsagt kunne have mulighed for at miskreditere ham. Melnik for det første, men dernæst også hans egen redaktør af Det nye Europa og tillige oversætter af Die Biologie des Krieges: Svend Borberg. Også han havde intim forbindelse til det tyske gesandtskab. Ved tidligere lejligheder havde Svend Borberg faktisk optrådt som en slags "dobbeltagent" for englænderne og tyskerne under verdenskrigen. 
Ifølge hans akter i Ausw. Amts Archiv ${ }^{42}$ trådte han i København i forbindelse med den engelske militærattaché i København, som han udførte spionageopgaver for i forsommeren 1916 på en rejse til Berlin, hvor han tillige optrådte som korrespondent for Berlingske Tidende. Hvad Borberg ikke meddelte sin engelske forbindelse var, at han under udførelsen af denne opgave konstant var i forbindelse med det tyske udenrigsministerium, og at han handlede i forståelse med det. Borberg fik i alt fald 1.500 kroner for sin ulejlighed fra det tyske gesandtskab. Hvad han fik fra engelsk side vides ikke. ${ }^{43}$ Borberg kunne som redaktør af Nicolais tidsskrift med største lethed have formidlet Nicolais brev videre til plantning i England i ubemærkethed, men det mest sandsynlige er, at Nicolai selv har gjort det.

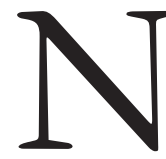
icolai-affæren er et eksempel på, at det selv for en personlighed med så høj en integritet som Georg Friedrich Nicolais alligevel ikke synes muligt at opretholde en position som fri, uafhængig eller neutral ånd. Alene det at skulle skabe forståelse for sine synspunkter på tværs af krigens fronter har på forhånd gjort en sådan opgave næsten uløselig.

Den påvirkning, som Nicolai kom til at udøve på samtiden bestod ikke $i$, at denne antog sig eller drøftede hans ideer om et fælles europæisk samfund eller om et verdenssamfund som sådan. Det afgørende for den stridende omverden, som Nicolai befandt sig i, var det langt mere begrænsede eller kortsynede: Hvem af parterne gavnede han? $\mathrm{Og}$ hvem så ham som en fjende? En tredie mulighed gaves ikke. Heri ligger den virkelige tragik. Det var ikke substansen af Nicolais synspunkter, der blev afgørende, men alene virkningen af dem. Var de skadelige? Eller var de til fordel? Kunne man ikke få Nicolai til at ændre holdning eller bringe ham i sådanne situationer, at han blev nødt til det, så kunne de krigsførende parter til gengæld bringe sig selv i sådanne positioner, at de - alt efter hvilken side, det drejede sig om - enten kompromitterede ham eller drog propagandamæssigt udbytte af hans position og meninger. Måske har hans kompromisløse holdning og den stejhed, der tydeligvis lå $\mathrm{i}$ hans personlighed heller ikke gjort det nemmere for ham.

Til en begyndelse havde Brandes været lidt imponeret af ham og egentlig sympatisk indstillet, men efter frokosten hos Brockdorff-Rantzau og efterhånden som Nicolai begyndte at stille krav til Brandes om aktiv medvirken i hans planer, ændrede hans holdning sig, således at han nærmet fandt Nicolai lidt gal, men i modsætning til Brandes havde han jo på sin egen krop oplevet at blive forfulgt af myndighederne i sit fædreland og havde gennemlevet en tid med personlig risiko.

En skikkelse som Nicolai kunne man næppe beskylde for ikke at besidde personlig integritet. Ej heller var det muligt at korrumpere eller manipulere ham til at ændre holdning. I sin kompromisløshed satte han ikke alene sin position i det storborgerlige tyske establishment over styr, men han løb også betydelig personlig risiko. 
Nicolai frigjorde sig i sin kamp for sine standpunkter fra så at sige ethvert personligt og karrieremæssigt hensyn, og han betalte høje omkostninger for det. Omverdenen forbandt hans personlighed med hans synspunkter, og Nicolai betalte den fulde pris som "fri ånd".

I 1922 måtte han forlade Tyskland. Hans værk Die Biologie des Krieges skaffede ham reputation som en krigens sociolog, og han endte som professor $\mathrm{i}$ sociologi ved universitetet i Córdoba i Argentina. Siden blev Chile hans hjemland, hvor han blev professor i fysiologi ved Veterinærhøjskolen i Santiago. Han døde i 1964.

\section{Noter}

1 Se Christophe Charle: Naissance des "intellectuels" 1890 - 1900. Paris 1990, samt Dietz Bering: Die Intellektuellen. Geschichte eines Schimpfwortes. Stuttgart 1978.

2 Se Wolf Zuelzer: Der Fall Nicolai, Frankfurt a. M. 1981, s. 26. Baggrunden for henvendelsen fra de 93 er beskrevet i Jürgen und Wolfgang von Ungern-Sternbergs bog Der Aufruf 'An die Kultunvelt', Franz Steiner Verlag, Stuttgart 1996.

3 Se Pierre Guiral: Clemenceau en son temps, Paris 1994, s. 158ff.

4 Wolf Zuelzer nævner i sin biografi over Georg Friedrich Nicolai, Der Fall Nicolai, Frankfurt a. M. 1981, at Erzberger stod bag opråbet, en opfattelse han har fra Nicolai. Se Der Fall Nicolai s. 26. Fritz Stern tilskriver i sin bog Einsteins World, Princeton 1999 forfatteren Ludwig Fulda æren for Aufruf an die Kulturwelt. s. 113. Det samme gør Jürgen og Wolfgang von Ungern-Sternberg. Ludwig Fuldas navn findes desuden blandt de 93. Ulrike Oppelt mener i sin disserta- tion Film und Propaganda im Ersten Welterieg, Beiträge zur Kommunikationsgeschichte, Bd. 10, Berlin 2002, s. 116, at opråbet var inspireret af den katolske professor i nationaløkonomi Lujo Brentano, der havde protesteret mod de allieredes fremstilling af den tyske krigsførelse som barbarisk.

5 Se Ausw. Amts Archiv, pk. 34. Rigsarkivet.

6 Smstds.

7 Se Wolf Zuelzer: Der Fall Nicolai, Frankf. a. M. 1981, s. 252.

8 Georg Friedrich Nicolai: Hvorfor jeg forlod Tyskland... i Det nye Europa, s. 20

9 Wolf Zuelzer: Der Fall Nicolai, Frankfurt a.M. 1981, s. $20 \mathrm{ff}$.

10 G. F. Nicolai: Die Biologie des Krieges, Zürich 1917, s. 11.

11 Se Wolf Zuelzer: Der Fall Nicolai, Frankf. a. M. 1981. s. 12ff. At forfatteren Leonhard Frank skulle have smuglet Nicolais manuskript ud af Tyskland som diplomatisk kurerpost er næppe rigtigt, dels var han velkendt som pacifist, dels var han allerede i exil i Schweiz i 1917.

$12 \mathrm{Da}$ første verdenskrig brød ud, var Romain Rolland på rejse i Schweiz. Krigsudbruddet medførte, at han forblev i Schweiz, hvor han engagerede sig i Røde Kors-arbejde og skrev imod krigen. 1915 fik han Nobelprisen.

13 I henhold til Dansk Boghandlertidende 1918, Dansk Bogfortegnelse, udkom E.D. Morels bog mellem den 11.4. - 17.4. Bogen udkom på Nordiske Forfatteres Forlag, der var finansieret af det tyske gesandtskab.

14 Georg Brandes Dagbog. Indførelse fra 22. Juni 1918. Brandes-arkivet III. 10. Kps. 197b, Det Kongelige Bibliotek.

15 Smstds. Indførelse fra 27. juni 1918.

16 Se Georg Brandes Dagbog 9. 61914. Georg Brandes-arkivet III Dagbøger 10. Kps. 197a, Det Kongelige Bibliotek.

17 Brev fra Josef Melnik til Georg Brandes 20. 4.1905. Georg Brandes-arkivet C. Breve fra Fremmede kps. 95, Det Kongelige Bibliotek.

18 Fremgår af Georg Brandes Dagbøger f.eks. 26 .9. 1914. Georg Brandes-arkivet 
III Dagbøger 10. kps. 197a. Det Kongelige Bibliotek.

19 Det omtales i en indberetning til Ausw. Amt fra det tyske gesandtskab i Kbh. den 18.2.1915, at Brockdorff-Rantzau skulle interessere sig særligt for Melnik. Se Ausw. Amts Archiv pk. 34, Rigsarkivet.

20 Fremgår af indberetning fra gesandtskabet til Ausw. Amt pk. 101, Rigsarkivet.

21 Georg Brandes: Dagbøger, indførelse af 22.6.1918. Georg Brandes-arkivet III Dagbøger 10. Kps. 197 b, Det Kongelige Bibliotek. De tyske militære myndigheders skepsis overfor Melnik er beskrevet i en skrivelse fra Ausw. Amts Nachrichtenabteilung til Brockdorff-Rantzau af 29. 7. 1918. Sagen synes således at have stået på en tid. Årsagen til denne modvilje mod Melnik kan have haft årsag i de militære myndigheders iagttagelse af hans forbindelse med Nicolai i Danmark.

22 Wolf Zuelzer: Der Fall Nicolai Frankf. a. M. 1981, s. 233.

23 Brev af 5.9.1917 fra Josef Melnik til Georg Brandes i Georg Brandes-arkivet Breve fra fremmede I C. kps. 15, Det Kongelige Bibliotek.

24 Georg Brandes: Dagbøger, indførelse af 20.7.1918 Georg Brandes-arkivet III Dagbøger 10. Kps. 197 b, Det Kongelige Bibliotek.

25 Der tænkes især på hans fremstilling af den danske, katolske digter Johs. Jørgensen som digterpersonlighed $\mathrm{i}$ en indberetning til rigskansleren efter publiceringen af bogen Klokke Roland, hvor Johs. Jørgensen havde angrebet den tyske krigsførelse i Belgien. Dette havde vakt stærk misfornøjelse hos den slesvig-holstenske ministerpræsident, der forlangte at udgivelsen af denne bog i Danmark skulle have politiske følger for kejserrigets forhold til Danmark, hvilket havde irriteret Brockdorff-Rantzau, der bestræbte sig for at opretholde et fredeligt forhold mellem de to nabolande. Se Jesper Düring Jørgensen: Tyske forsøg på kulturpropaganda i Danmark under Den første Verdenskrig i Fund og Forskning bd.
XXVI. Kbh. 1982, s. 139, hvor affæren er gengivet.

26 Josef Melnik til Georg Brandes 27.6.1918. Brandesarkivet I C. Breve til Georg Brandes fra Fremmede. Kps. 95, Det Kongelige Bibliotek.

27 Georg Brandes: Dagbøger indførelse af 30.6.1918. Georg Brandes-arkivet III Dagbøger 10. Kps. 197 b, Det Kongelige Bibliotek.

28 Smstds. 2.7.1918.

29 Smstds. 1.9.1918.

30 Georg Friedrich Nicolai til Georg Brandes 23.9.1918 Brandesarkivet I C. Breve fra fremmede. Kps. 103, Det Kongelige Bibliotek.

31 Wolf Zuelzer: Der Fall Nicolai, Frankf. a. M. 1981, s. 235.

32 Når begge versioner forekommer i Det Kongelige Bibliotek er grunden, at de blev trykt i Danmark, hvorfor de er blevet pligtafleveret til Det Kongelige Bibliotek.

33 Wolf Zuelzer: Der Fall Nicolai, Frankf. a. M. 1981, s. 227.

34 Smstds. s. 238.

35 Georg Brandes: Der Tragödie 2. Teil. Der Friedensscbluss. Brücken IV. Gotha 1920.

36 Georg Brandes: Dagbøger indførelser af 15.10., 16.10., 19.10., 20.10. og 21.10. 1918. Georg Brandes-arkivet III Dagbøger 10. Kps. 197 b, Det Kongelige Bibliotek.

37 Georg Friedrich Nicolai til Georg Brandes 26.10.1918 Brandesarkivet I C. Breve fra fremmede. Kps. 103. Det Kongelige Bibliotek.

38 Georg Brandes Dagbøger, Brandes-arkivet, kps. 197 b. DetKongelige Bibliotek.

39 Smstds.

40 Wolf Zuelzer: Der Fall Nicolai. Frankf. a. M. 1981, s. 237.

41 Georg Brandes Dagbøger, Brandes-arkivet, kps. 197 b. Det Kongelige Bibliotek.

42 Se Ausw. Amts Archiv pk. 375 Rigsarkivet.

43 Smstds. Under anden verdenskrig fungerede Svend Borberg som propagandamager for den tyske besættelsesmagt. Han tiltaltes for disse aktiviteter efter besættelsen under det danske retsopgør. Ved 
byretten idømtes han 4 års fængsel, men

frikendtes ved Landsretten. Han døde i

1947. Se Ditlev Tamm: Retsopgoret efter besat-

telsen, Kbh. 1984, s. 599.

Denne artikel er en udvidet version af en arti-

kel bragt i Weekendavisen 26.10.2007.

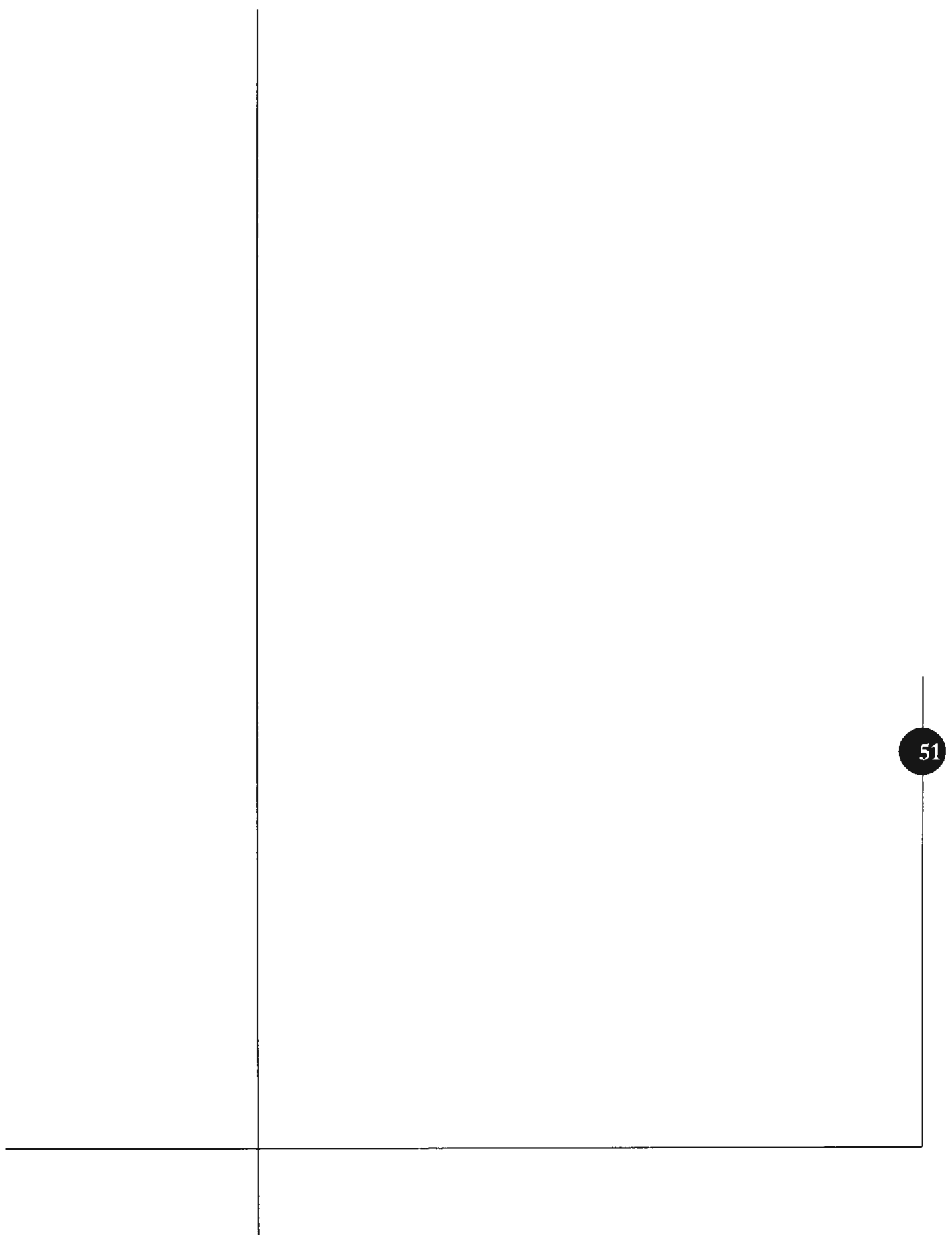

